\title{
Microbial Keratinases: Enzymes with Promising Biotechnological Applications
}

\section{Beti Vidmar and Maša Vodovnik*}

Chair of Microbiology and Microbial Biotechnology, Department of Animal Science, Biotechnical Faculty, University of Ljubljana, Groblje 3,

SI-1230 Domžale, Slovenia

Received: 3 January 2018 Accepted: 31 May 2018

\author{
*Corresponding author: \\ Phone: +38613203955; \\ Fax: +38617241005; \\ E-mail:masa.vodovnik@bf.uni-lj.si
}

\begin{abstract}
SUMMARY
Keratin is a complex and structurally stable protein found in human and animal hard tissues, such as feathers, wool, hair, hoof and nails. Some of these, like feathers and wool, represent one of the main sources of protein-rich waste with significant potential to be transformed into value-added products such as feed, fertilizers or bioenergy. A major limitation impeding valorization of keratinous substrates is their recalcitrant structure and resistance to hydrolysis by common proteases. However, specialized keratinolytic enzymes produced by some microorganisms can efficiently degrade these substrates. Keratinases have already found a purpose in pharmaceutical, textile and leather industries. However, their wider implementation in other processes, such as cost-effective (pre)treatment of poultry waste, still requires optimization of production and performance of the available enzymes. Here we present a comprehensive review covering molecular properties and characteristics of keratinases, their classification, traditional and novel approaches in discovery of novel enzymes, production, characterization, improvement and biotechnological applications.
\end{abstract}

Key words: keratin, keratinase, waste degradation, keratinolytic microorganisms, biotechnological applications

\section{INTRODUCTION}

Corneous (hornlike) tissues have a specific role in vertebrates, representing a protective barrier between the organism and its environment. The major building blocks, defining properties such as the degree of rigidity and hardness of corneous tissues, are specialized structural proteins named keratins (1). Due to their protective role, the structure of these proteins is very recalcitrant and resistant to the degradation by widespread enzymes (2). While this property is primarily an evolutionary advantage of humans and animals possessing corneous tissues, it also represents a significant challenge for industrial waste management (3). Industrial poultry processing (feathers) and sheep farming (low quality wool) produce large amounts of keratin-rich waste. This type of protein-rich waste holds a significant potential for the transformation into value-added products or bioenergy (4). However, current mainstream strategies of keratinous waste valorization involve physical/chemical (pre)treatment of the substrates that are not environmentally friendly. A promising alternative approach that might solve this issue would be the application of cost-effective proteolytic enzymes, specialized for the degradation of these substrates (3). Although the potential of keratinases for various biotechnological applications has long been recognized, the knowledge on these enzymes and their mechanisms of action on the substrate, production and optimization still needs to be expanded in order to make their industrial use feasible. The aim of the following review is to approach comprehensively current knowledge on various aspects of these enzymes and their production that may be helpful for future research.

\section{KERATIN AS A SUBSTRATE}

The three-dimensional structure of the first keratin molecule was first described in 1959, but the number of studies in this area increased extensively after 1990 (5). Currently, there are at least 30 different keratin polypeptides classified into various groups, depending on 
their unique physicochemical properties, molecular structure and the producing epithelial cells (6). Keratins are resistant to degradation by conventional proteases (pepsin, trypsin) and insoluble in diluted acids, alkaline reagents, water and organic solvents (7). The amino acid sequence and composition of keratins affect their folding, properties and functions of keratin filaments. Cysteine plays a key role in the formation of disulphide bonds, important for structural stability of these molecules (6). Hard keratins (found in hard excrescences, such as feathers, hair, nails and hooves) contain more disulphide bonds than soft, flexible keratins. Amino acid sequence also affects the secondary structure of keratins, which may be enriched in a-helix (typical for a-keratins) or $\beta$-sheet structures (typical for $\beta$-keratins) (8).

Keratins typically consist of three domains with different secondary structures: head domain, central helical domain and tail domain (6). Head domain, or $\mathrm{N}$-terminal part of protein, is a globular structure with $\beta$-turns consisting of variable number of amino acids (50-100) with a positive net charge. Central helical domain of a-keratins comprises approx. 310 amino acids and consists of four right-handed a-helical subdomains (1A, 1B, 2A and $2 B$ ), which are separated from one another by non-helical $\beta$-turns called "linker" regions. The latter differ in their amino acid sequence and length (9). Approximately 38-45\% keratin molecule is in the a-helical conformation (10). Tail domain or C-terminal part of protein contains globular structure. The domains and subdomains of one keratin molecule interact with those of adjacent keratin molecules forming heterodimers, tetramers and, finally, keratin fibres. The rod domains of one acidic and one basic keratin molecule in parallel orientation form heterodimers of keratin molecules, and represent the building blocks of keratin filaments (11).

Quaternary structure of keratins has an effect on the capacity for the formation of a tetramer (protofilament with a diameter of $2 \mathrm{~nm}$ ) (12), an octamer (protofibril, two protofilaments, with a diameter of $4.5 \mathrm{~nm}$ ) (13) and unit length filaments (ULFs) with a diameter of $20 \mathrm{~nm}$ (14), comprising four bundled protofibrils (15). Structures of protofibrils and microfibres are strengthened by disulphide bonds, hydrogen and hydrophobic interactions, which also play a crucial role in rigidity and recalcitrance of keratin molecules (16).

\section{KERATINASES: PROTEASES WITH SPECIFIC PROPERTIES AND MODE OF ACTION}

Proteases are ubiquitous in nature as they are involved in many biological reactions, both at cellular and whole organism levels and have an important ecological role in circulation of nitrogen in nature (16-18). Proteases are classified as hydrolytic enzymes that may either cleave peptide bonds near the ends of polypeptide chain (exoproteases) or inside the chains (endoproteases). According to the amino acid sequences in the enzyme active sites and associated catalytic mechanisms, proteases can be classified into seven broad groups: serine, cysteine, threonine, aspartic and glutamic proteases, metalloproteases and asparagine peptide lyases $(17,19)$. The sequencing era introduced the need for upgraded classification system based on sequence similarities, also reflecting evolutionary relationships between the proteolytic enzymes. Considering this structure-based classification, the database MEROPS was established, in which peptidases are currently organized into 62 clans and 268 families (MEROPS, edition 12.0, 2018) $(20,21)$.

Keratinases (EC 3.4.21) are the only group of proteases with a wide temperature and $\mathrm{pH}$ range that allow complete degradation of complex and recalcitrant proteins (8). The unique characteristic that distinguishes keratinases from other proteases is the ability to bind to the complex and insoluble substrates (feathers, wool, silk, collagen, elastin, horns, stratum corneum, hair, azokeratin and nails) (8). Although the mechanism of enzyme adsorption is not yet well understood, it is known that the higher the adsorption capacity, the higher the degree of keratin hydrolysis (22). After enzyme binding and cleavage of disulphide bonds, keratin changes its conformation and exposes multiple sites for hydrolytic action of the enzymes (21). According to the nature of their active site, keratinases belong to serine- and metalloproteases or serine metalloproteases (8). Serine proteases are functionally rich and diverse group of proteases with nucleophilic serine residues (Ser) located in the enzyme active site. The latter attacks carbonyl part of the peptide bond in order to form an acyl-enzyme intermediate (23). More than 333000 serine proteases are known so far and classified in 53 families and 16 clans (MEROPS, edition 12.0, 2018) (24). In metalloproteases, nucleophilic attack on the peptide bond can be transmitted through water molecules coordinated by the enzyme's divalent metallic ion (usually Zn(II) and occasionally cobalt or manganese) or bimetallic centre (two $\mathrm{Zn}$ (II) ions or one $\mathrm{Zn}(\mathrm{II})$ and $\mathrm{Co}(\mathrm{II}) / \mathrm{Mn}$ (II) ion) (22). Depending on the required number of metal ions for catalysis, metalloproteases can be divided in two groups: first group requires two metal ions with co-catalytic mode of action, while the second group only requires one (22). Approximately 294000 metallopeptidases have been identified so far and classified into 73 families and 15 clans (MEROPS, edition 12.0, 2018) (24).

Keratinases are robust enzymes with diverse biochemical properties. Most of them are monomeric, although there are descriptions of some multimeric enzymes (25). Molecular mass of bacterial keratinases ranges from 18 (enzyme SK1-02 from Streptomyces albidoflavus) to $200 \mathrm{kDa}$ (enzymes from Kocuria rosea and Fervidobacterium islandicum), while the enzymes of pathogenic fungi can reach up to $440 \mathrm{kDa}$ (for example keratinase II of Trichophyton mentagrophytes) $(8,24,25)$. Higher molecular masses are often characteristic of metalloproteases and originate from thermophilic microorganisms (21).

\section{METHODS OF DETECTION OF KERATINOLYTIC ACTIVITY}

\section{Qualitative and semi-quantitative methods}

Qualitative methods for keratinolytic activity detection on solid matrix are usually appropriate for the initial assessment of the samples either when screening for keratinolytic strains 
or enzyme fractions. Commonly known assays for protease activity detection apply agar/agarose plates, with incorporated target substrate (26). A commonly applied variation of this method is the radial diffusion test, where the proteolytic activity is proportional to hydrolysis zones around small holes in agar plate containing immobilized substrate (27). This type of screening media used different substrates, including e.g. $0.1 \%$ wool (28), feather meal (25), hair $(29,30)$, keratin powder, soy flour, etc. The applied substrates typically also act as enzyme inducers, however, it is essential that the screening medium be free of repressors and inhibitors of target enzymes such as pepstatin, high concentrations of dextrose or glucose (31).

Zymography is used as a semi-quantitative method for keratinase detection on solid phase, since it has several advantages over other methods (32). This highly sensitive method allows the identification of specific active proteases in complex enzyme mixtures. While the rest of the qualitative and semi-quantitative methods serve exclusively for screening tests, zymography offers the information on molecular masses of the separate enzymes in the extracts (33).

\section{Quantitative methods}

After initial isolation of keratinolytic strain or specific enzyme(s), quantification of keratinolytic activity under different conditions is usually of interest as a key part of further target characterization. Quantitative methods allow exact determination of proteolytic activity in a liquid phase (spectrophotometry, fluorimetry, radiometry, chromatography, capillary electrophoresis and enzyme-linked immunosorbent assays are generally used) (32). Keratinolytic activity in protein extracts may be determined using a variety of insoluble chromogenic substrates (examples are keratin azure, azocasein, azokeratin, etc.) $(34,35)$. Enzyme extract is typically mixed with the substrate suspension and incubated at the appropriate temperature. Afterwards, centrifugation of samples removes the insoluble substrate and the absorbance at the appropriate wavelength detects the release of the product (dye) (32).

\section{THE MECHANISM OF MICROBIAL KERATIN DEGRADATION}

Despite the resistance to most proteolytic enzymes, keratins do not accumulate in nature, which indicates the presence of naturally occurring keratinolytic microorganisms. These constantly contribute to the recycling of the carbon, nitrogen and sulphur by the degradation of vast amounts of keratinous waste (hair and bird's feathers, etc.) $(8,36)$.

Cleavage of peptide bonds in compact molecules, such as keratins, is challenging, particularly due to insolubility and difficult access of target peptide bonds. Enzymatic degradation of keratin is a multistage process that requires the following steps: (i) adsorption of the keratinases to the surface of macromolecule by electrostatic and hydrophobic interactions, followed by (ii) catalytic action. Multistage process of keratin degradation includes two major processes: sulfitolysis or reduction of disulfide bonds and proteolysis $(8,37)$. Sulfitolysis can only take place in the presence of reducing compounds such as sodium sulfide, dithiothreitol (DTT), mercaptoethanol, glutathione, cysteine, thioglycolic acid or disulfide reductases, which act in cooperation with keratinases in the degradation of keratin molecules $(8,38)$.

\section{REGULATION OF MICROBIAL EXPRESSION OF KERATINASES}

Microbial production of proteolytic enzymes is a complex and highly regulated process, dependent on the microbial growth stage $(39,40)$. Most keratinases are considered inducible enzymes, but some are also expressed constitutively $(41,42)$. Nevertheless, it is important to note that constitutive expression of proteases is mostly associated with caseinolytic and not keratinolytic activity, and it is suggested that the keratinolytic enzymes are mainly inducible (8).

The production is typically most intensive at the end of the exponential and/or in stationary phase, which is associated with the adaptation to the lack of nutrients (40). This suggests that the production or secretion of proteases may be regulated by nutritional stress, such as the lack of carbon and nitrogen sources. The lack of amino acids in the medium typically affects the cellular GTP concentrations. Under the conditions of high nutrient availability, the concentration of GTP is very high, thus maintaining a transcriptional repressor CodY in phosphorylated/active form. The binding of the repressor to the operator prevents transcription of the gene encoding for specific enzyme. Limitation of nutrients reduces GTP concentrations and consequently inactivates CodY (43).

\section{MICROBIAL SOURCES OF KERATINASES}

Keratinases are ubiquitous in nature and can be found in representatives from the three domains of life: Eukarya, Bacteria and Archaea. The degradation of keratin is more abundant among Gram-positive than the Gram-negative bacterial genera (8). The ability of keratin degradation has so far been reported for strains of Bacillus licheniformis (44), B. pumilus, B. cereus, B. subtilis (45) and non-sporogenic bacteria Stenotrophomonas sp. (38), Fervidobacterium pennavorans (46), F. islandicum (23), Lysobacter sp. (35), Nesterenkonia sp. (47) and Kocuria sp. (48). There are also reports that representatives of some Gram-negative genera degrade this substrate: Vibrio sp. (49), Xanthomonas sp. (50), Thermoanaerobacter sp. (51), Stenotrophomonas sp. (52) and Chryseobacterium sp. (53). Descriptions of thermophilic and extremophilic keratinolytic representatives from genera Fervidobacterium sp. (54), Thermoanaerobacter sp. (51) and Bacillus sp. (55) are also available.

In addition, at least 300 known fungal species have been reported so far to use keratin as a nutrient source $(56,57)$. Keratinolytic fungi represent dermatophytes (Microsporum, Epidermophyton and Trichophyton) and related species of the genus Chrysosporium. Non-dermatophytic keratinolytic fungi are found in two genera, Chrysosporium and Myceliophthora 
(anamorph) (56). Most keratinolytic groups of fungi belong to fungi imperfecti, including the following genera: Aspergillus, Alternaria, Trichurus, Curvularia, Cladosporium, Fusarium, Geomyces, Gleomastis, Monodictys, Myrothecium, Paecilomyces, Stachybotrys, Urocladium, Scopulariopsis, Sepedonium, Penicillium and Doratomyces (8). The primary steps of keratin degradation by fungi involve mechanical attack on the substrate by their mycelium in addition to sulfitolysis $(21,58,59)$.

\section{INDUSTRIALLY IMPORTANT PRODUCERS OF KERATINASES}

The main industrial producers of serine proteases are strains belonging to the genus Bacillus $(60,61)$. This genus has an important role in white biotechnology for several reasons it is very well studied, majority of species are non-pathogenic, generally recognized as safe (for example B. cereus, B. stearothermophilus, $B$. licheniformis, $B$. subtilis and so on) and many functional extracellular proteins are secreted directly into the culture medium $(60,62)$. Other promising producers are representatives of the genus Streptomyces (S. rectus var. proteolyticus, S. griseus, S. moderatus NRRL 3150, Streptomyces sp. YSA 2130, S. diastaticus SS1, S. corchorusii ST36, S. pactum DSM 40530) and actinomycetes Nocardiopsis and Oerskovia (63-65). Among the most industrially important psychrotrophic bacterial genera are Pseudoalteromonas, Colwellia, Flavobacterium and Shewanella. The enzymes from these organisms are effective at low temperatures due to adaptive structural flexibility $(66,67)$.

Archaea represent an important source of extremophilic proteases for biotechnological applications as well as fundamental research. Brandelli et al. (21) have reported a hot spring isolate, belonging to Desulfurococcales (labelled 1507-2), capable of keratin degradation at $70^{\circ} \mathrm{C}$ and $\mathrm{pH}=6$.

\section{SEARCH FOR NOVEL KERATINASES VIA ISOLATION OF NOVEL KERATINOLYTIC STRAINS}

The industry has a great interest in microorganisms that are capable of producing large amounts of efficient extracellular keratinases $(33,68,69)$. Isolation of novel strains producing significant yields of well performing target enzymes is a prerequisite for the development of a viable industrial fermentation process. If the strains themselves are not easy to cultivate, they may represent a source of keratinase genes that can be expressed in another, already established production host. The environment represents an unlimited source of new keratinolytic strains for the implementation of new industrial processes and improvement of the existing ones $(40,70,71)$. Usually, peculiar microecosystems in which microorganisms have to adapt to the lack of nitrogen/carbon sources other than keratin represent the best sources of these enzymes $(33,68,69)$. During isolation, strains are usually first screened for their keratinolytic potential by qualitative or semi-quantitative methods (screening media), followed by more sophisticated molecular and biochemical methods of characterization (72).

Although keratinases from various microorganisms have already been extensively studied, there is still a demand for new ones with improved industrial properties such as higher catalytic efficiency on keratinous substrates, increased stability at elevated temperature and/or $\mathrm{pH}$ values and higher tolerance to feedback inhibition (73). Apart from strain isolation-dependent methods, other approaches are also in use to increase the number and variability of the available enzymes. These include cloning of genes encoding novel enzymes directly from the metagenomes and modifications of the existent enzymes by protein engineering (Fig. 1).

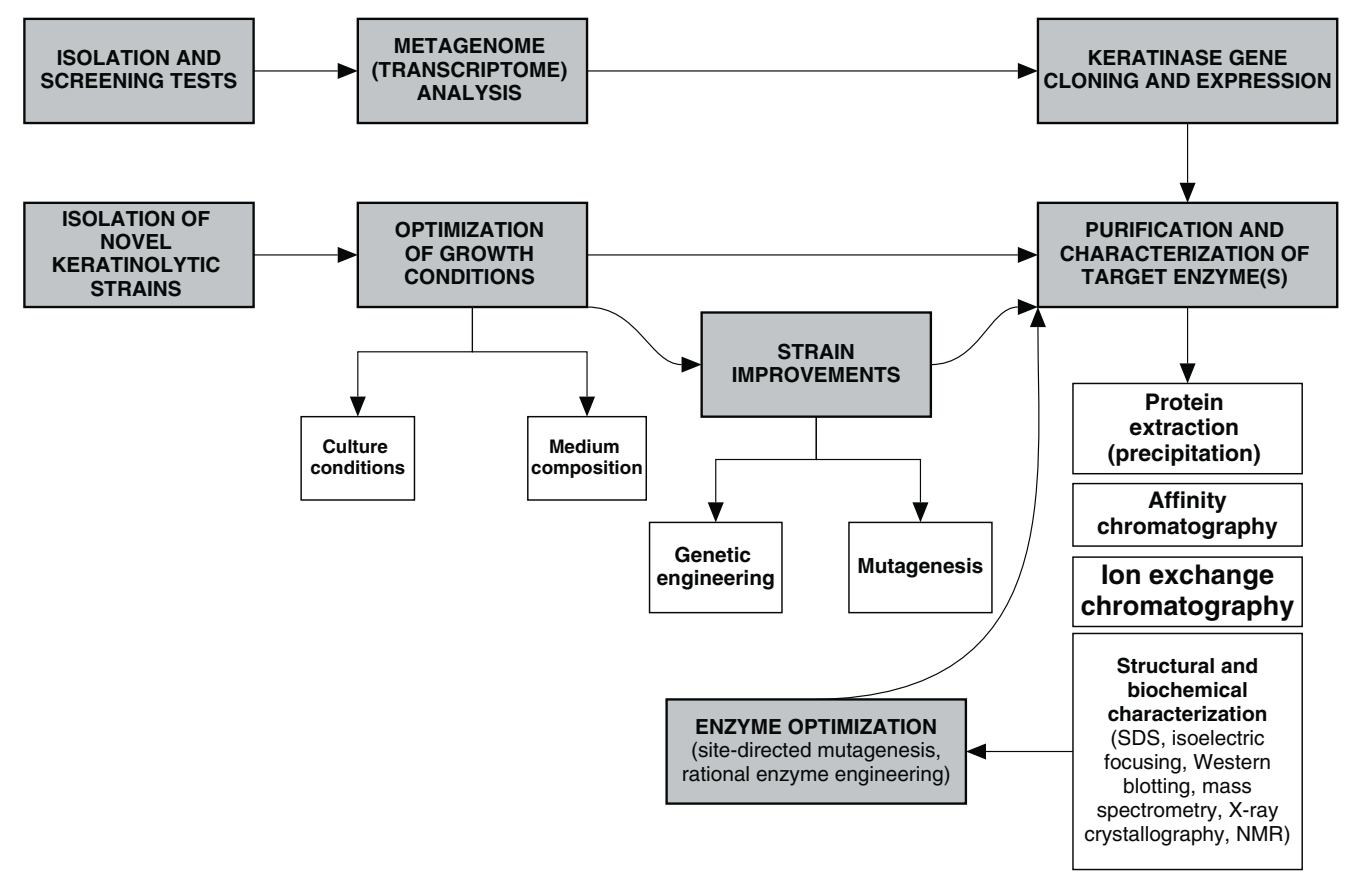

Fig. 1. Different approaches used for identification, production and characterization of novel keratinases and optimization of their performance 


\section{CULTIVATION-INDEPENDENT METHODS FOR IDENTIFICATION OF NOVEL KERATINASES}

Majority of currently described and applied keratinases originate from isolated microbial strains. However, it is estimated that more than $99 \%$ of microorganisms from natural environments have not yet been isolated, which greatly reduces the number of available microbiological sources $(73,74)$.

Sequencing of environmental metagenomes allows us to directly identify genes coding for enzymes with predicted activities via comparison to structurally similar sequences in the databases $(75,76)$. Moreover, functional metagenomics allows the detection of novel enzymes with no structural similarities to the already known enzymes. In addition, proteomic and transcriptomic tools give us an information on the expression of target genes in specific conditions and explore their mechanisms of action (77-81).

\section{Metagenomic approaches}

Metagenomics appeared at the end of the last century as an alternative approach to conventional microbial screening of environmental samples $(82,83)$. Metagenomic sequence analyses enable the reconstruction of the global enzyme potential in the environmental sample - an information on total consortium of enzymes encoded in examined microbial community $(84,85)$.

Research strategies for accessing novel biocatalysts include (optional) pretreatment of genes of interest, nucleic acid extraction, vector and host selection and the screening of metagenomic libraries. Extracting and purification of the sample DNA is a critical step in the process, since the construction of a metagenomic library requires a sufficient amount of high-quality DNA. The next step in building a metagenomic library is the selection of an appropriate vector and host systems, which depends on the characteristics of the environmental samples and intended purpose of the constructed database (82).

A selection of proper vector determines whether heterologous DNA will successfully enter the host cells and be actively expressed (the latter is important for functional metagenomics, which is an experimental approach for studying gene function). The choice of a vector system depends on the quality of the extracted DNA and research goals, taking into account the size of inserted fragments, the required number of copies of the vector, type of the used host strain and potential methods of screening. Plasmids, bacterial artificial chromosomes (BACs), cosmids and fosmids are commonly in use (82).

Currently, the most widely used cloning and expression host is Escherichia coli. However, many eukaryotic genes cannot be functionally expressed in E. coli, due to the lack of appropriate mechanisms of post-translational modifications, which makes the development and establishment of new, alternative host systems extremely important (86). So far there have been reports of microorganisms such as Streptomyces sp. and Pseudomonas sp. applied as host strains for the construction of metagenomic libraries (87).
An unbiased manner to mine natural microbial communities for new keratinases is by screening expression library for the desired enzymatic activity. To allow for an efficient route for mining new enzymes, high-throughput approaches have to be adapted that will allow to rapidly screen $10^{6}-10^{8}$ samples (88). The enzymatic activity is usually tested on solid matrices supplemented with keratinous substrate. By screening metagenomic library on the plates, positive clones can be identified through a visual examination of discolouration or staining zones around enzyme-producing colonies (89). This type of screening does not necessarily require extra devices and can be performed at high-throughput level, but the signals are often poor, which may be the reason for low hit rate. Some alternative approaches can improve the sensitivity of agar-based screening. One strategy with improved sensitivity involves the growth of cell library in microtiter plates, followed by chemical or physical lysis and activity detection (90-92). If agar plates are used, targeted activities can be linked to the survival of host organisms, which makes screening or selection sensitive and high-throughput. Another strategy is screening of large libraries by multiple cycles of enrichment using flow cytometry or selective immobilization of active clones (88).

The genes encoding target enzymes represent a very small portion of the (meta)genome and in some cases even less than $0.01 \%$ of total sample of nucleic acids derives from environmental sources. Low abundance of target genes in the library plays a key role in the selection of mining strategy (93). Metagenomic approaches therefore sometimes involve custom-designed oligonucleotide hybridization probes, which hybridize to specific sequences in metagenomic libraries. For example, catalytic triplet Asp191, His252 and Ser441 are highly conserved regions with a strong preservation in oxyanion region in all keratinases. These regions can be used for designing probes for identification of new keratinases in unexplored sources (19).

Another type of target metagenomic enrichment method is stable-isotope probing (SIP) (94), in which microorganisms grow in the presence of isotopically labelled substrates. Due to metabolic activity, the isotopes (usually ${ }^{13} \mathrm{C}$ or ${ }^{15} \mathrm{~N}$ ) are incorporated exclusively in macromolecules of the microbes that metabolize the target substrate (keratin). This increases the target organism's DNA or RNA density that can later be separated from unlabelled molecules (94). High density DNA then serves as a template to amplify the functional genes involved in the selected metabolic pathways by PCR, which allows the study of active microorganisms involved in the processes (95). Combining pyrosequencing with SIP allows metagenomics of high resolution that targets specific enzymes (75).

\section{Transcriptomics}

A major disadvantage of approaches based on (meta) genomic library sources of novel enzymes is the high percentage of non-coding and/or non-target DNA regions, which unnecessarily increase the size of the library and (in the case of eukaryotic DNA) need to be removed in order to produce functional 
enzymes. In addition to the problems related to the incorrect gene positioning with respect to its promoters, non-excised introns and the differential codons usage, post-translational modifications may also represent a problem when expressing these genes in heterologous hosts (96). The advantage of using cDNA libraries is that most of the non-encoding DNA elements are removed, reducing the size of libraries to the genes that are actively expressed in certain conditions (97).

\section{MOLECULAR CLONING AND HETEROLOGOUS EXPRESSION OF KERATINASES}

Oftentimes, cloning of keratinase genes in a host that can easily be manipulated is essential for ensuring industrial enzyme yields needed for commercialization of the products. Heterologous expression hosts, which are specifically adapted for abundant production of target enzymes, produce more than $50 \%$ of industrially important keratinases. Currently, keratinase expression using heterologous systems would lay the foundation for its genetic manipulation, protein engineering and large scale enzyme preparation (98). Properties and original source of the enzyme to be expressed affect the choice of the type of heterologous host (which is usually bacterium or yeast strain). Increased production can be achieved by two strategies: (i) inserting the plasmid that contains the gene coding for keratinase under a strong promotor, or (ii) using a strain with more keratinase genes integrated in the chromosome.

Despite the fact that $E$. coli is a preferred expression system for recombinant proteins, the bottleneck of producing the protein in this host is accumulation of inactive inclusion bodies and requirement of in vitro folding of pro-keratinases, which drastically affects final active enzyme yield $(8,19)$. If expression host does not enable correct protein folding, additional procedures have to be introduced for proper formation of disulfide bridges (99). Other expression hosts, like Bacillus strains, are also used. In these strains, the significant enzyme yield and higher production have been achieved with the introduction and expression of multiple copies of keratinase genes (e.g. in B. subtilis DB104 and B. licheniformis T399D) (100). Despite many advantageous features of Bacillus sp., the use of this host may be limited due to reported plasmid instability (100). In addition, some species (for example B. licheniformis) produce significant amounts of indigenous extracellular enzymes (amylases, mannanases, cellulases) which may adversely affect the downstream processes (101). Other expression hosts are also being used for heterologous keratinase production, for example yeast Pichia pastoris, which provides a good environment for the appropriate post-translational modifications and protein folding of eukaryotic keratinases. In addition, this unicellular eukaryote is simple for culturing and manipulations and has so far been successfully used for expression of many proteases from bacteria, fungi and mammals (102). One of the successful examples of heterologous expression of keratinase in P.pastoris was the production of $B$. licheniformis MKU keratinase, which exhibited increased thermostability $\left(75 \%\right.$ retained activity at $\left.80^{\circ} \mathrm{C}\right)$ in comparison with the protein produced in $B$. megaterium expression system (19). Other examples of heterologous expression of keratinases are in Table 1 (38,84,103-107).

\section{METHODS FOR IMPROVEMENT OF KERATINASE PERFORMANCE AND PRODUCTION}

Many times optimization of specific properties of enzymes (such as $\mathrm{pH}$, temperature stability or specificity) or associated genetic elements that regulate their production is necessary to ensure cost-effective production/performance of the target. This can either be done by traditional non-targeted approaches, such as physical (108) and chemical mutagenesis (109) or by the protein engineering approaches (110). Different options are described below.

\section{Physical (UV irradiation-induced) and chemical mutagenesis}

Non-ionizing radiation (for example by UV light) results in the excitation of electrons in DNA molecules, which typically results in mutagenic effect. Random mutations in structural gene or regulatory elements may have positive or negative effect on the production and properties of target enzymes. According to Zeng et al. (111), UV irradiation of Deinococcus ficus CC-ZG207 mutants caused a 2-fold increase in keratinase production, in comparison to the wild type strain (101).

Table 1. Examples of keratinase genes expressed in heterologous expression systems

$\begin{array}{ccccc}\text { Original source of keratinase gene } & \begin{array}{c}\text { Accession } \\ \text { number of } \\ \text { cloned gen }\end{array} & \text { Host strain for cloning and overexpression } & \text { Vector type } & \text { Reference } \\ \text { Bacillus licheniformis MKU3 } & \text { DQ071570 } & \text { Escherichia coli BL21 } & \text { pET30b } & (103) \\ \text { Bacillus licheniformis MKU3 } & \text { DQ071570 } & \text { Bacillus megaterium ATCC 14945 } & \text { pWH1520 } & (103) \\ \text { Bacillus licheniformis MZK-05 } & \text { Q9FDF4 } & \text { Escherichia coli BL21; Esherichia coli DH5a } & \text { pGEX-6p-2 } & (104) \\ \text { Bacillus licheniformis PWD-1 } & \text { S78160 } & \text { Bacillus subtilis DB104 } & \text { pJCD } & (84) \\ \text { Bacillus circulans DZ100 } & \text { KC621294 } & \text { Escherichia coli BL21 } & \text { pABT2 } & (104) \\ \text { Bacillus pumilus KS12 } & \text { KC814159 } & \text { Escherichia coli } & \text { pEZZ18 } & (105) \\ \text { Geobacillus stearothermophilus } & \text { KJ783444 } & \text { Escherichia coli BL21(DE3) } & \text { pTZ57R/T } & (106) \\ \text { AD-11 } & - & \text { Escherichia coli AD494(DE3)pLysS } & \text { pET-43b(+) } & (107) \\ \text { Pseudomonas aeruginosa } & \text { KC763971 } & \text { Escherichia coli BL21 (DE3) } & \text { pET22b } & (38) \\ \text { Stenotrophomonas maltophilia } & \text { BBE11-1 } & & & \end{array}$


Chemical agents, such as ethyl methylsulfonate (EMS), N-methyl-N'-nitro-N-nitroso-guanidine (MNNG) or ethidium bromide, can also induce random mutations in DNA molecules. Exposing B. subtilis to MNNG, for example, resulted in 2,5-fold higher keratinase activity in mutated strain than in the wildtype (109). Brevibacillus sp. AS-S10-II treatment with EMS resulted in mutants having a higher growth rate and keratinase production (101).

\section{Protein engineering}

Molecular methods for improvement of biocatalysts (or regulatory elements affecting their production) is usually performed by one of the following approaches: the rational design or directed evolution.

\section{Rational design}

Rational protein design is an effective strategy, which requires the information on the relationship between the sequence, structure and function of target enzymes. It is based on the comparison of the target sequence (predicted structure) to the already characterized enzymes, which allows the prediction and modification of the residues responsible for specific functional properties of the enzyme, substrate and co-factor binding sites, thermostability or enantioselectivity. Novel binding sites for metal ions, active sites, etc. can also be introduced into the protein (106). Site-directed mutagenesis is a method that applies target changes in double-stranded DNA, resulting in a modified amino acid sequence and tertiary structure of the enzyme (112). It is typically used to improve the thermostability, efficiency, activity of keratinases or enzyme yield (promotor mutagenesis) (103). Thermostability of $B$. licheniformis BBE11-1 keratinase has been improved by using a computer design (algorithm PoP$\mathrm{MuSiC})$, which was applied for predicting change of free energy of amino acid substitutions. Afterwards, four amino acid substitutions (N122Y, N217S, A193P and N160C) were introduced into the enzyme, using site-directed mutagenesis and mutated genes were later on expressed in B. subtilis WB600. The amino acid replacement $\mathrm{N} 122 \mathrm{Y}$ caused 5,6-fold increase in the catalytic efficiency, in comparison to wild-type keratinase $(101,104)$.

Specific nucleases Pstl and Kpnl were used for improving stability of serine proteases from Bacillus sp., for which oxidation-sensitive methionine 222 was removed and replaced by non-oxidizing amino acid (Ser, Ala or Leu). Consequently, protease mutants, containing modified amino acids, were more resistant to chemical oxidation (105).

The relatively rapid PCR-based method used in rational design involves splicing by overhang extension (SOE) (106) that generates improved protein variants containing modified (specific) amino acid. This method offers several advantages - it is simple, fast and highly repeatable and does not require restriction enzymes or DNA ligases to generate site-directed mutations (106).

Engineering of enzyme immobilization enables the improvement of the efficiency, thermostability and other enzyme characteristics. According to Wang et al. (113) immobilization of keratinases of genus Bacillus sp. can be achieved by fusion of two genes - kerA, encoding keratinase, and stp, encoding streptavidin, which binds to biotin. Fusion construct kerA-stp allowed formation of a recombinant protein keratinase-streptavidin, which was secreted into the medium. Fusion protein was then isolated from the medium using biotinylated beads. This method of immobilization substantially improved the thermostability and $\mathrm{pH}$ tolerance of the enzyme (101).

\section{Directed evolution}

Directed evolution is one of the most effective approaches to tailor biocatalysts for industrial purposes (106). Fundamentally, it is an imitation of Darwinian evolution on a laboratory scale, based on sequential random mutagenesis and selection steps (114). This approach has already been used to improve a whole series of enzymes for which the structure-function relationship was not known (115).

The first step in directed evolution is the introduction of numerous random point mutations by PCR and/or recombination, resulting in the emergence of many molecular variants of a wild-type gene. Point mutations can be introduced using error-prone PCR, for example by substituting $\mathrm{Mg}^{2+}$ with other type of cations (e.g. $\mathrm{Mn}^{2+}$ ) or by the application of highly error-prone polymerase. Another possible way of generating novel gene variants is DNA shuffling, which is based on recombination of related genes and also allows the generation of proteins with improved properties. Gene shuffling results in different combinations of hybrid genes, originating from different origin cells or even species (106).

Successful selection of engineered enzymes requires a "high-throughput" screening method, which considerably increases the chance of obtaining desired properties and reduces the time and cost of the analysis (116). Emerging new technologies that provide sufficient performance are necessary to support the testing of millions of samples in a highly reproducible manner. The most convenient strategy for the detection of enzymes involves the use of chromogenic or fluorogenic substrates (107). This strategy is based on the ability of bacteria harbouring the target genes to selectively convert substrates to detectable products. A high-throughput method for single cell screening can be applied by microfluidic droplet sorting yielding improved production hosts for secreted enzymes, which results from an improvement of the cellular functions of the production host. Enzymes producing single cells are encapsulated in 20-pL droplets with a fluorogenic reporter substrate. The platform enables small reagent consumption for a screening experiment, which greatly reduces the costs of screening and engineering of production strains (107).

Recent progress in high-throughput enzyme assays has included analytical instruments for parallel screening, thermistor arrays, new fluorogenic and chromogenic substrates, as well as novel applications of $\mathrm{pH}$ indicator methods (117). 


\section{BIOTECHNOLOGICAL APPLICATIONS OF KERATINASES}

Microbial enzymes represent a significant share of industrial catalysts, hydrolases taking approx. $65 \%$ of the market (40). Among the latter, proteases are an extremely important group of enzymes due to their broad applicability scope $(40,118)$. In addition to broad substrate specificity, keratinases stand out from other proteases due to general robustness, which is advantageous in many industrial applications. Fig. 2 shows different (potential) applications of keratinases, while the most common commercial products already on the market are shown in Table 2 (72,119).

\section{Processing and cleaning of animal hides - leather industry}

Leather industry is one of the oldest, fast-growing industries in the world and plays an important role in today's economy. At the same time, it is considered as one of the world's biggest sources of pollution, as leather processing includes use of toxic substances, causing hazardous effects on the environment and workers in industrial plants (60).

The treatment of hides involves a series of processes, among which pre-tanning is considered as a major source of pollution (8). Chemicals such as sodium sulfide, lime and solid wastes, arising as a result of the preliminary tanning, are the main reason for the increase in biochemical oxygen demand

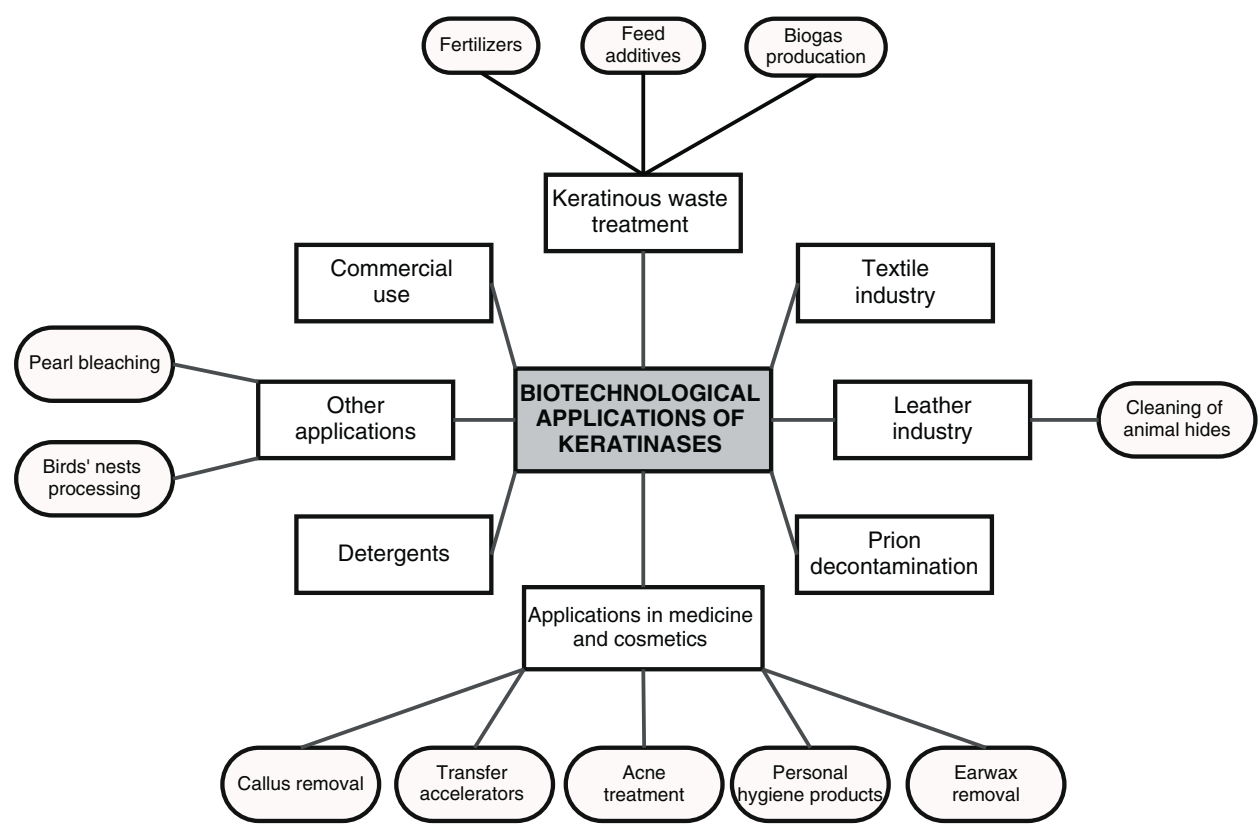

Fig. 2. Biotechnological and industrial applications of keratinases

Table 2. Commercially available keratinase products

\begin{tabular}{|c|c|c|c|}
\hline Application & Description of the product & Commercial product & Reference \\
\hline Earwax removal & $\begin{array}{l}\text { Successful, safe and effective removal of earwax from the } \\
\text { external ear canal }\end{array}$ & Zymox & (72) \\
\hline Corn and callus removal & $\begin{array}{l}\text { Keratinases present natural alternative to the use of acids } \\
\text { for corn and callus removal }\end{array}$ & $\begin{array}{c}\text { Keratoclean }{ }^{\circledR} \text { Hydra PB, PURE } \\
100 \text { Keratinase }\end{array}$ & (72) \\
\hline Acne treatment & $\begin{array}{l}\text { Acne is caused by blockage of sebaceous glands in } \\
\text { the presence of large quantities of keratin, therefore } \\
\text { keratinases can be used for successful treatment }\end{array}$ & $\begin{array}{l}\text { Keratoclean }^{\circledR} \text { Sensitive PB, } \\
\quad \text { Keratopeel }^{\circledR} \text { PB }\end{array}$ & $(72,119)$ \\
\hline $\begin{array}{l}\text { Commercial use (poultry } \\
\text { feed) }\end{array}$ & $\begin{array}{l}\text { Keratinase product improves the feed ratio and has a } \\
\text { positive effect on chicken body mass }\end{array}$ & Versazyme $^{\circledast}$ & (72) \\
\hline $\begin{array}{l}\text { Commercial use (poultry } \\
\text { feed) }\end{array}$ & $\begin{array}{l}\text { Enzyme product reduces cost of cooking and temperature } \\
\text { processing of feather, therefore increasing the digestibility } \\
\text { and nutritional value of feed }\end{array}$ & Valkerase $^{\circledR}$ & (72) \\
\hline Prion decontamination & $\begin{array}{l}\text { Effective decontamination of medical instruments from } \\
\text { prions. It contains engineered protease with increased } \\
\text { activity, broader specificity and thermostability }\end{array}$ & Prionzyme ${ }^{T M}$ & (72) \\
\hline $\begin{array}{l}\text { Biomedical, pharmaceutical } \\
\text { and cosmetics }\end{array}$ & $\begin{array}{l}\text { Keratinase product is supposed to regulate the } \\
\text { concentration of keratin in pores, therefore helping to } \\
\text { eliminate blisters, keratinized skin, it can be used for } \\
\text { treatment of dermatophytic and nail diseases, scars and } \\
\text { epithelial regeneration }\end{array}$ & PURE100 Keratinase & (72) \\
\hline Cleaning agents & $\begin{array}{l}\text { Cleaning pipes and tanks with different enzymes, } \\
\text { including keratinases }\end{array}$ & Bioguard Plus & (72) \\
\hline
\end{tabular}


(BOD), chemical oxygen demand (COD) and total quantity of dissolved solids (TDS) in wastewater produced in these plants (8). The enzyme practice is a green alternative leading to reduction in environmental pollution and improves the leathers (120). Proteolytic enzymes are nowadays increasingly used for hide softening to improve pliability of the hides and prepare them for tanning process. Various keratinolytic enzyme preparations for the removal of animal hair without damaging the skin (collagen) are also in use. They selectively degrade the soft keratin tissue in the follicle, thereby pulling out intact hair without affecting tensile strength of the leather (121). Enzymes, mainly originating from Bacillus sp. (122-126), Pseudomonas stutzeri (127), Caldicoprobacter algeriensis (128), Acinetobacter sp. (129), Paenibacillus woosongensis (130), Vibrio metschnikovii (131) and different fungi from species Aspergillus tamarii (132), Penicillium chrysogenum and Trichoderma harzianum have been reported to be used in leather industry $(133,134)$. The application of keratinases in leather industry improves the quality of the final product, and reduces environmental pollution by chemicals, providing a safer working environment $(60,135)$.

\section{Detergent and textile industry}

Alkaline proteases represent $89 \%$ of proteolytic enzymes used in detergent industry (8). Enzymes suitable for use in detergents need to be compatible with other components of the washing agents, and exhibit activity and stability at higher $\mathrm{pH}$ values and temperatures. The alkaline keratinase from Paenibacillus woosongensis TKB2 is one of the enzymes with potential application in the laundry industry for removing the composite stains without affecting the fabric texture, fibres and strength of clothes (130).

Textile industry uses keratinases for processing wool fibres. Wool is composed of structural proteins with high degree of cross-linked disulfide bridges that give fibres mechanical strength and resistance to degradation. This is attributed to the overlapping layers of the epidermis (epi-, exo- and endocuticle) (136). Epicuticle is rich in lipids, while the exo- and endocuticle are composed of keratin. The epidermis plays a key role in fibre contraction during washing and dyeing processes. Shrinkage has traditionally been controlled using absorbable organic chlorides. The disadvantages of this process include loss of natural wool character, yellowing of material, pollution of waste water with AOX (adsorbable organically bound halogens), affected biodegradability of fabric (caused by limited bioavailability) and high energy and time consumption (137). Environmentally safe alternatives to the chemicals used in this process are enzyme preparations, typically composed of proteases and lipases. The role of proteases is to remove an outer layer of coarse fibre, reducing the rough feeling of the wool. It is necessary to carefully dose the enzymes, as some proteases penetrate deep into fibres, causing their damage, loss of mass and tensile strength (138). This is also the reason why currently no process is exclusively based on enzymes. To some extent, penetration can be limited by increasing the molecular mass of proteases aimed for this application by chemical crosslinking, attachment of synthetic polymers, etc. (33). A better alternative is the use of specific keratinases that selectively act only on keratinous layers of the wool, without adverse effects on the other fibre parts (137).

\section{Decontamination of prions with keratinases}

Prions are very robust, compact proteins that cause serious neurodegenerative diseases, such as TSEs (transmissible spongiform encephalopathies) (19). Due to increased number of prion horizontal transmissions from animals to humans (including iatrogenic transmissions via contaminated surgical tools), effective methods for decontamination of material infected with prions are of vital importance. Since conventional methods are based on aggressive and energetically demanding processes, enzymatic degradation of prions may be a promising approach for destruction of these highly aggregated proteins with structural similarities to keratin. So far there have been reports of only two keratinases used for prion decontamination purposes - one isolated from $B$. licheniformis PWD-1 (137) and the other from Streptomyces sp. (139). Nevertheless, in addition to enzymatic treatment, further treatment of infected material with alkaline reagents, detergents and high temperatures is required.

\section{Applications in medicine and pharmacy}

Keratinases are also used in cosmetic industry for treatment of acne, calluses, keratinized and dry skin removal, treatment of psoriasis, etc. $(140,141)$. Applications of keratinases in pharmaceutical industry are mainly associated with improving the passage of fungicidal drugs through the keratinous nail surface. Nail disorders, mainly associated with fungal infections, are ranging from relatively harmless (pigmentation), to painful conditions such as nail dystrophy (142). Treatment of fungal infections of nails (onychomycosis) is extremely challenging and traditionally involves long-term consumption of antifungal medicines and repeated monthly injections with corticosteroids, causing many side effects, such as rashes and liver damage (143). An alternative form of treatment is a topical application of antimycotic drugs directly to the affected area. The main drawback of this approach is impermeability of the nail surface which affects drug penetration and treatment efficiency. A variety of mechanical (nail abrasions and separation), physical (etching, laser treatment, hydration and fast closing of nails) and chemical methods (keratinolytic agents, such as urea, thioglycolic acid, salicylic acid, $\mathrm{N}$-acetyl cysteine, mercaptoethanol) are being used for improving the medicine transfer to the site of action (144). However, these chemicals are only effective in high concentrations and may have a pungent smell (137). Keratinases, on the other hand, may be very effective in loosening the nail plates already in low concentrations, which was first demonstrated by keratinase from Paecilomyces marquandii $(137,143)$. 
Transformation of keratinous waste to bioenergy and value-added products

According to regulation (EC) 1774/2002 (145) of the European parliament, keratinous waste is classified as the third category of animal products, meaning: (i) it is obtained from animal carcases, (ii) is not intended for human consumption, and (iii) should not transmit diseases to humans or animals (145). Large amounts of waste produced by animal processing plants can be used as a substrate for bioenergy and value-added products if properly treated prior to their use. Traditional treatment of keratinous waste includes the use of alkaline and acidic hydrolysis, processing at high pressure and high temperatures (up to $150^{\circ} \mathrm{C}$ ) (146). Despite the aforementioned advantages, these methods are expensive, consume large amounts of energy and lead to loss of some essential amino acids important for subsequent production of value-added products or bioenergy $(33,147)$.

\section{Production of feather meal for feed industry, bioenergy production and agriculture}

The main waste in poultry industry are feathers, representing 7-10\% of chicken mass. In 2012, around 8.5 billion tonnes of poultry feather were generated worldwide (148). Feathers consist of about $90 \%$ keratin (majority being $\beta$-keratin) and contain large amounts of serine, glutamic acid, proline and small amounts of methionine, histidine and lysine (145). Several million tonnes of feathers per year represent one of the biggest waste byproducts of poultry industry, and an important source of environmental pollution $(8,149)$. One of the options for valorization of feather waste involves their transformation to the feather meal, which can be used as a raw material in biodiesel production, an ingredient in bioplastics or as animal feed (150). Traditional processing of feathers includes high temperature and pressure, which are the cause of high costs and destruction of some essential amino acids (methionine, lysine and tryptophan). Consequently, final products may be poorly digestible and have a variable nutritional value (8). Such shortcomings can be avoided by enzymatic hydrolysis of feathers by keratinases, resulting in production of higher quality amino acids that can be supplemented to poultry, pig, ruminant and fish feeds $(8,150)$.

Hydrolyzed feathers can also be converted to bio-hydrogen (119), or used as a fertilizer for organic farming that allows slow release of nitrogen, improves plant growth, promotes soil microbial activity, structures the soil and increases its water retention capacity (8).

\section{Anaerobic digestion of keratinous waste for the production of biogas}

Anaerobic digestion is a promising process for microbial production of renewable energy from different types of waste substrates. During this process, substrates are hydrolysed to amino acids, which are later converted to a variety of organic acids, ammonia, carbon dioxide, hydrogen and minor amounts of sulphur compounds. These are the substrates for methanogenesis - a microbial process in which acetate, hydrogen and carbon dioxide are used to produce methane and carbon dioxide (151). Anaerobic degradation of feathers runs under thermophilic $(151)$ or mesophilic $(151,152)$ conditions and usually includes different types of waste (manure, mixed bone fractions, leftovers and offal).

Theoretical methane yield from proteins is $0.496 \mathrm{~m}^{3} / \mathrm{kg}$ of volatile solids (VS) $(153,154)$, but only around $0.21 \mathrm{~m}^{3} / \mathrm{kg}$ was reported to have been produced from waste feathers (155). Low yield is the result of low accessibility of nutrients due to compact keratin ultrastructure in feathers and can be increased by pretreatment (156). In recent years different chemical, physical and enzymatic methods of pretreatment are being explored $(155,157)$. Development of some recombinant keratinolytic strains with increased production of enzymes aims to increase and improve keratinous waste decomposition before/during anaerobic digestion (155). A recombinant $B$. megaterium strain carrying $B$. licheniformis keratinase gene was developed in order to increase hydrolysis of chicken feathers. The recombinant strain effectively degraded feathers prior to biogas production, which resulted in production of up to $80 \%$ of the theoretical methane yield originating from protein digestion. The positive effect is due to the fact that a strong inducible promotor controls the keratinase production in B. megaterium, resulting in a prompt and efficient turnout of enzymes without lag phase (158).

\section{Other applications}

Keratinases are also used in a variety of other applications, including for bioaugmentation of composting of keratin-rich waste (159), for modifications of basic structure of fibres in wool or silk (8), in different cosmetic products and processing of edible bird's nests. One of the unconventional applications is in pearl bleaching. At the time of bead formation, organic impurities such as free cells, mucus cells and necrotic tissue may be present in the layer of mounting. Therefore it is necessary to improve the quality of beads prior to sale. The pearls are traditionally treated by gentle bleaches (hydrogen peroxide) that can provide soft lightening, although they can offset their colouring and may affect colour irregularity. Zhang et al. (160) reported using keratinases as an alternative for the traditional-type bleaching process.

\section{CONCLUSIONS}

The application of keratinases in some areas of industry is already well established, while they remain a promising tool for agriculture and food industry waste management. The main bottlenecks limiting wider application of many currently available enzymes are their efficiency on complex natural substrates (such as feather and poor-quality wool), low stability and/or high production costs. Different approaches are increasingly emerging to overcome these obstacles with 
the goal to make the use of these enzymes for the aforementioned applications cost-effective. Protein engineering and directed evolution are among the most promising strategies to optimize currently available enzymes, while the decrease in the costs of the DNA sequencing is making it possible to expand the consortium of the currently available enzymes with new ones. The development of novel molecular tools may on the other hand enable efficient genome editing of the available and novel producing strains, making the keratinase production more affordable. Future efforts to replace current environmentally questionable practices with enzyme-based treatments of (keratinous) wastes are of significant importance as they may contribute to long-term welfare of humanity, climate change and maybe even survival of the species.

\section{REFERENCES}

1. Ferraro V, Anton M, Santé-Lhoutellier V. The "sisters" a-helices of collagen, elastin and keratin recovered from animal by-products: Functionality, bioactivity and trends of application. Trends Food Sci. 2016;51:65-75.

https://doi.org/10.1016/j.tifs.2016.03.006

2. Lv LX, Sim MH, Li YD, Min J, Feng WH, Guan WJ, Li YQ. Production, characterization and application of a keratinase from Chryseobacterium L99 sp. nov. Process Biochem. 2010;45(8):1236-44. https://doi.org/10.1016/j.procbio.2010.03.011

3. Tomlinson DJ, Mülling $\mathrm{CH}$, Fakler TM. Invited review: Formation of keratins in the bovine claw: roles of hormones, minerals, and vitamins in functional claw integrity. J Dairy Sci. 2004;87(4):797-809.

https://doi.org/10.3168/jds.S0022-0302(04)73223-3

4. Brandelli A, Sala L, Kalil SJ. Microbial enzymes for bioconversion of poultry waste into added-value products. Food Res Int. 2015;75:3-12.

https://doi.org/10.1016/j.foodres.2015.01.015

5. Brandelli A. Bacterial keratinases: Useful enzymes for bioprocessing agroindustrial wastes and beyond. Food Bioprocess Technol. 2008;1(2):105-16. https://doi.org/10.1007/s11947-007-0025-y

6. Bragulla $\mathrm{HH}, \mathrm{Homberger} \mathrm{DG.} \mathrm{Structure} \mathrm{and} \mathrm{functions} \mathrm{of} \mathrm{ker-}$ atin proteins in simple, stratified, keratinized and cornified epithelia. J Anat. 2009;214(4):516-59.

https://doi.org/10.1111/j.1469-7580.2009.01066.x

7. Steinert PM, Wantz ML, Idler WW. O-phosphoserine content of intermediate filament subunits. Biochemistry. 1982;21(1): 177-83.

https://doi.org/10.1021/bi00530a030

8. Gupta R, Ramnani P. Microbial keratinases and their prospective applications: An overview. Appl Microbiol Biotechnol. 2006;70:21-33.

https://doi.org/10.1007/s00253-005-0239-8
9. Parry DAD, Marekov LN, Steinert PM. Subfilamentous protofibril structures in fibrous proteins: Cross-linking evidence for protofibrils in intermediate filaments. J Biol Chem. 2001; 276:39253-8.

https://doi.org/10.1074/jbc.M104604200

10. Steinert PM. The extraction and characterization of bovine epidermal a-keratin. Biochem J. 1975;149(1):39-48.

https://doi.org/10.1042/bj1490039

11. Er Rafik M, Doucet J, Briki F. The intermediate filament architecture as determined by X-ray diffraction modeling of hard alpha-keratin. Biophys J. 2004;86(6):3893-904. https://doi.org/10.1529/biophysj.103.034694

12. Eichner R, Kahn M. Differential extraction of keratin subunits and filaments from normal human epidermis. J Cell Biol. 1990;110(4):1149-58.

https://doi.org/10.1083/jcb.110.4.1149

13. Herrmann H, Aebi U. Intermediate filaments: Molecular structure, assembly mechanism, and integration into functionally distinct intracellular scaffolds. Annu Rev Biochem. 2004;73:749-89.

https://doi.org/10.1146/annurev.biochem.73.011303.073823

14. Herrmann H, Wedig T, Porter RM, Lane EB, Aebi U. Characterization of early assembly intermediates of recombinant human keratins. J Struct Biol. 2002;137(1-2):82-96.

https://doi.org/10.1006/jsbi.2002.4466

15. Parry DAD, North ACT. Hard a-keratin intermediate filament chains: Substructure of the $\mathrm{N}$-and $\mathrm{C}$-terminal domains and the predicted structure and function of the C-terminal domains of type I and type II chains. J Struct Biol. 1998;122(12):67-75.

https://doi.org/10.1006/jsbi.1998.3967

16. Hsiao NW, Chen Y, Kuan YC, Lee YC, Lee SK, Chan HH, Kao $\mathrm{CH}$. Purification and characterization of an aspartic protease from the Rhizopus oryzae protease extract, peptidase R. Electron J Biotechnol. 2014;17:89-94.

https://doi.org/10.1016/j.ejbt.2014.02.002

17. Oda K. New families of carboxyl peptidases: Serine-carboxyl peptidases and glutamic peptidases. J Biochem. 2012; 151(1):13-25.

https://doi.org/10.1093/jb/mvr129

18. Page MJ, Di Cera E. Serine peptidases: Classification, structure and function. Cell Mol Life Sci. 2008;65(7-8):1220-36. https://doi.org/10.1007/s00018-008-7565-9

19. Gupta R, Sharma R, Beg QK. Revisiting microbial keratinases: Next generation proteases for sustainable biotechnology. Crit Rev Biotechnol. 2013;33(2):216-28. https://doi.org/10.3109/07388551.2012.685051

20. Rawlings ND, Barrett AJ, Bateman A. MEROPS: The database of proteolytic enzymes, their substrates and inhibitors. Nucleic Acids Res. 2012;40(D1):343-50. https://doi.org/10.1093/nar/gkr987 
21. Brandelli A, Daroit DJ, Riffel A. Biochemical features of microbial keratinases and their production and applications. Appl Microbiol Biotechnol. 2010;85(6):1735-50. https://doi.org/10.1007/s00253-009-2398-5

22. Supuran CT, Scozzafava A, Clare BW. Bacterial protease inhibitors. Med Res Rev. 2002;22(4):329-72. https://doi.org/10.1002/med.10007

23. Nam GW, Lee DW, Lee HS, Lee NJ, Kim BC, Choe EA, et al. Native-feather degradation by Fervidobacterium islandicum AW-1, a newly isolated keratinase-producing thermophilic anaerobe. Arch Microbiol. 2002;178(6):538-47. https://doi.org/10.1007/s00203-002-0489-0

24. Rawlings ND, Morton FR, Barrett AJ. MEROPS: the peptidase database. Nucleic Acids Res. 2004;32(Suppl.1):160-4. https://doi.org/10.1093/nar/gkh071

25. Fang Z, Zhang J, Liu B, Du G, Chen J. Biochemical characterization of three keratinolytic enzymes from Stenotrophomonas maltophilia BBE11-1 for biodegrading keratin wastes. Int Biodeterior Biodegrad. 2013;82:166-72.

https://doi.org/10.1016/j.ibiod.2013.03.008

26. Vijayaraghavan P, Vincent SGP. A simple method for the detection of protease activity on agar plates using bromocresolgreen dye. J Biochem Tech. 2013;4(3):628-30.

27. Gupta R, Beg QK, Khan S, Chauhan B. An overview on fermentation, downstream processing and properties of microbial alkaline proteases. Appl Microbiol Biotechnol. 2002; 60(4):381-95.

https://doi.org/10.1007/s00253-002-1142-1

28. Gegeckas A, Gudiukaitè R, Citavicius D. Keratinolytic proteinase from Bacillus thuringiensis AD-12. Int J Biol Macromol. 2004;69:46-51.

https://doi.org/10.1016/j.ijbiomac.2014.05.024

29. Queiroga AC, Pintado MM, Malcata FX. Novel microbial-mediated modifications of wool. Enzyme Microb Technol. 2007;40(6):1491-5.

https://doi.org/10.1016/j.enzmictec.2006.10.037

30. Queiroga AC, Pintado ME, Malcata FX. Potential use of wool-associated Bacillus species for biodegradation of keratinous materials. Int Biodeterior Biodegrad. 2012;70:60-5. https://doi.org/10.1016/j.ibiod.2011.12.013

31. Kainoor PS, Naik GR. Production and characterization of feather degrading keratinase from Bacillus sp. JB 99. Indian J Biotechnol. 2010;9:384-90.

32. Santos ACGCQ. Novel wild bacterial enzymes for applications in the wool industry [PhD Thesis]. Lisboa, Portugal: Technical University of Lisbon; 2011.

33. Queiroga AC, Pintado ME, Malcata FX. Search for novel proteolytic enzymes aimed at textile and agro-industrial applications: An overview of current and novel approaches. Biocatal Biotransform. 2012;30(1):154-69.

https://doi.org/10.3109/10242422.2012.650856
34. Daroit DJ, Corrêa APF, Brandelli A. Keratinolytic potential of a novel Bacillus sp. P45 isolated from the Amazon basin fish Piaractus mesopotamicus. Int Biodeterior Biodegrad. 2009; 63(3):358-63.

https://doi.org/10.1016/j.ibiod.2008.11.008

35. Pereira JQ, Lopes FC, Petry MV, da Costa Medina LF, Brandelli A. Isolation of three novel Antarctic psychrotolerant feather-degrading bacteria and partial purification of keratinolytic enzyme from Lysobacter $\mathrm{sp}$. A03. Int Biodeterior Biodegrad. 2014;88:1-7. https://doi.org/10.1016/j.ibiod.2013.11.012

36. Farag AM, Hassan MA. Purification, characterization and immobilization of a keratinase from Aspergillus oryzae. Enzyme Microb Technol. 2004;34(2):85-93.

https://doi.org/10.1016/j.enzmictec.2003.09.002

37. Ramnani P, Gupta R. Keratinases vis-à-vis conventional proteases and feather degradation. World J Microbiol Biotechnol. 2007;23(11):1537-40. https://doi.org/10.1007/s11274-007-9398-3

38. Yamamura S, Morita Y, Hasan Q, Yokoyama K, Tamiya E. Keratin degradation: a cooperative action of two enzymes from Stenotrophomonas sp. Biochem Biophys Res Commun. 2002;294(5):1138-43. https://doi.org/10.1016/S0006-291X(02)00580-6

39. Voigt B, Hoi LT, Jürgen B, Albrecht D, Ehrenreich A, Veith B, et al. The glucose and nitrogen starvation response of Bacillus licheniformis. Proteomics. 2007;7(3):413-23.

https://doi.org/10.1002/pmic.200600556

40. Daroit DJ, Brandelli A. A current assessment on the production of bacterial keratinases. Crit Rev Biotechnol. 2013;34(4):372-84.

https://doi.org/10.3109/07388551.2013.794768

41. Manczinger L, Rozs M, Vágvölgyi C, Kevei F. Isolation and characterization of a new keratinolytic Bacillus licheniformis strain. World J Microbiol Biotechnol. 2003;19(1):35-9. https://doi.org/10.1023/A:1022576826372

42. Gessesse A, Hatti-Kaul R, Gashe BA, Mattiasson B. Novel alkaline proteases from alkaliphilic bacteria grown on chicken feather. Enzyme Microb Technol. 2003;32(5):519-24. https://doi.org/10.1016/S0141-0229(02)00324-1

43. Sonenshein AL. CodY, a global regulator of stationary phase and virulence in Gram-positive bacteria. Curr Opin Microbiol. 2005;8(2):203-7.

https://doi.org/10.1016/j.mib.2005.01.001

44. Lin X, Wong SL, Miller SE, Shih JC. Expression of the Bacillus licheniformis PWD-1 keratinase gene in B. subtilis. J Ind Microbiol Biotechnol. 1997;19(2):134-8.

https://doi.org/10.1038/sj.jim.2900440

45. Kim JM, Lim WJ, Suh HJ. Feather-degrading Bacillus species from poultry waste. Process Biochem. 2001;37(3):287-91. https://doi.org/10.1016/S0032-9592(01)00206-0 
46. Friedrich AB, Antranikian G. Keratin degradation by Fervidobacterium pennavorans, a novel thermophilic anaerobic species of the order Thermotogales. Appl Environ Microbiol. 1996;62(8):2875-82.

47. Gopinath SCB, Anbu P, Lakshmipriya T, Tang TH, Chen Y, Hashim $U$, et al. Biotechnological aspects and perspective of microbial keratinase production. Biomed Res Int. 2015; Article ID 140726.

https://doi.org/10.1155/2015/140726

48. Bernal C, Cairó J, Coello N. Purification and characterization of a novel exocellular keratinase from Kocuria rosea. Enzyme Microb Technol. 2006;38(1-2):49-54. https://doi.org/10.1016/j.enzmictec.2005.02.021

49. Sangali S, Brandelli A. Feather keratin hydrolysis by a Vibrio sp. strain kr2. J Appl Microbiol. 2000;89(5):735-43. https://doi.org/10.1046/j.1365-2672.2000.01173.x

50. De Toni CH, Richter MF, Chagas JR, Henriques JAP, Termignoni C. Purification and characterization of an alkaline serine endopeptidase from a feather-degrading Xanthomonas maltophilia strain. Can J Microbiol. 2002;48(4):342-8. https://doi.org/10.1139/w02-027

51. Kublanov IV, Tsiroulnikov KB, Kaliberda EN, Rumsh LD, Haertlé T, Bonch-Osmolovskaya EA. Keratinase of an anaerobic thermophilic bacterium Thermoanaerobacter sp. strain 1004-09 isolated from a hot spring in the Baikal Rift zone. Microbiology. 2009;78(1):67-75. https://doi.org/10.1134/S0026261709010093

52. Fang Z, Zhang J, Liu B, Jiang L, Du G, Chen J. Cloning, heterologous expression and characterization of two keratinases from Stenotrophomonas maltophilia BBE11-1. Process Biochem. 2014;49(4):647-54. https://doi.org/10.1016/j.procbio.2014.01.009

53. Park GS, Hong SJ, Jung BK, Khan AR, Park YJ, Park CE, et al. Complete genome sequence of a keratin-degrading bacterium Chryseobacterium gallinarum strain DSM 27622T isolated from chicken. J Biotechnol. 2015;211:66-7. https://doi.org/1010.1016/j.jbiotec.2015.07.007

54. Kanoksilapatham W, Pasomsup P, Keawram P, Cuecas A, Portillo MC, Gonzalez JM. Fervidobacterium thailandense sp. nov., an extremely thermophilic bacterium isolated from a hot spring. Int J Syst Evol Microbiol. 2016;66:5023-7. https://doi.org/10.1099/ijsem.0.001463

55. Sen S, Satyanarayana T. Optimization of alkaline protease production by thermophilic Bacillus licheniformis S-40. Indian J Microbiol. 1993;33:43-7.

56. Błyskal B. Fungi utilizing keratinous substrates. Int Biodeterior Biodegrad. 2009;63(6):631-53. https://doi.org/10.1016/j.ibiod.2009.02.006

57. Solazzo C, Dyer JM, Clerens S, Plowman J, Peacock EE, Collins MJ. Proteomic evaluation of the biodegradation of wool fabrics in experimental burials. Int Biodeterior Biodegrad. 2013;80:48-59.

https://doi.org/10.1016/j.ibiod.2012.11.013
58. Mitola G, Escalona F, Salas R, García E, Ledesma A. Morphological characterization of in-vitro human hair keratinolysis, produced by identified wild strains of Chrysosporium species. Mycopathologia. 2003;156(3):163-9.

https://doi.org/10.1023/A:1023340826584

59. Moreira FG, de Souza CGM, Costa MAF, Reis S, Peralta RM. Degradation of keratinous materials by the plant pathogenic fungus Myrothecium verrucaria. Mycopathologia. 2007;163(3):153-60.

https://doi.org/10.1007/s11046-007-0096-3

60. Jaouadi B, Aghajari N, Haser R, Bejar S. Enhancement of the thermostability and the catalytic efficiency of Bacillus pumilus CBS protease by site-directed mutagenesis. Biochimie. 2010;92(4):360-9.

https://doi.org/10.1016/j.biochi.2010.01.008

61. Maeda T, Yoshimura T, García-Contreras R, Ogawa HI. Purification and characterization of a serine protease secreted by Brevibacillus sp. KH3 for reducing waste activated sludge and biofilm formation. Bioresour Technol. 2011; 102(22):10650-6.

https://doi.org/10.1016/j.biortech.2011.08.098

62. Vavrová L, Muchová K, Barák I. Comparison of different Bacillus subtilis expression systems. Res Microbiol. 2010; 161(9):791-7.

https://doi.org/10.1016/j.resmic.2010.09.004

63. Aksoy SÇ, Uzel A, Hameş Kocabaş EE. Extracellular serine proteases produced by Thermoactinomyces strains from hot springs and soils of West Anatolia. Ann Microbiol. 2012; 62(2):483-92.

https://doi.org/10.1007/s13213-011-0280-z

64. DemirT, Gübe Ö, Yücel M, Hameş Kocabaş EE. Increased alkalotolerant and thermostable ribonuclease (RNase) production from alkaliphilic Streptomyces sp. M49-1 by optimizing the growth conditions using response surface methodology. World J Microbiol Biotechnol. 2013;29(9):1625-33.

https://doi.org/10.1007/s11274-013-1325-1

65. Demir T, Hameş EE, Öncel SS, Vardar-Sukan F. An optimization approach to scale up keratinase production by Streptomyces sp. 2 M21 by utilizing chicken feather. Int Biodeterior Biodegrad. 2015;103:134-40.

https://doi.org/10.1016/j.ibiod.2015.04.025

66. Mageswari A, Subramanian P, Chandrasekaran S, Karthikeyan S, Gothandam KM. Systematic functional analysis and application of a cold-active serine protease from a novel Chryseobacterium sp. Food Chem. 2017;217:18-27. https://doi.org/10.1016/j.foodchem.2016.08.064

67. Wang QF, Hou YH, Xu Z, Miao JL, Li GY. Purification and properties of an extracellular cold-active protease from the psychrophilic bacterium Pseudoalteromonas sp. NJ276. Biochem Eng J. 2008;38(3):362-8.

https://doi.org/10.1016/j.bej.2007.07.025 
68. Queiroga AC, Pintado ME, Malcata FX. Wool-associated proteolytic bacteria, isolated from Portuguese Merino breed. Small Rumin Res. 2013;109(1):38-46.

https://doi.org/10.1016/j.smallrumres.2012.09.005

69. Schumacher K, Heine $E$, Höcker H. Extremozymes for improving wool properties. J Biotechnol. 2001;89(2-3):281-8. https://doi.org/10.1016/S0168-1656(01)00314-5

70. van Beilen JB, Li Z. Enzyme technology: An overview. Curr Opin Biotechnol. 2002;13(4):338-44. https://doi.org/10.1016/S0958-1669(02)00334-8

71. Sanchez S, Demain AL. Enzymes and bioconversions of industrial, pharmaceutical, and biotechnological significance. Org Process Res Dev. 2011;15(1):224-30. https://doi.org/10.1021/op100302x

72. Kumar CG, Takagi H. Microbial alkaline proteases: From a bioindustrial viewpoint. Biotechnol Adv. 1999;17(7):561-94. https://doi.org/10.1016/S0734-9750(99)00027-0

73. Duan CJ, Feng JX. Mining metagenomes for novel cellulase genes. Biotechnol Lett. 2010;32(12):1765-75. https://doi.org/10.1007/s10529-010-0356-z

74. Rappé MS, Giovannoni SJ. The uncultured microbial majority. Annu Rev Microbiol. 2003;57:369-94.

https://doi.org/10.1146/annurev.micro.57.030502.090759

75. Fernández-Arrojo L, Guazzaroni ME, López-Cortés N, Beloqui A, Ferrer M. Metagenomic era for biocatalyst identification. Curr Opin Biotechnol. 2010;21(6):725-33.

https://doi.org/10.1016/j.copbio.2010.09.006

76. Sharma VK, Kumar N, Prakash T, Taylor TD. MetaBioME: A database to explore commercially useful enzymes in metagenomic datasets. Nucleic Acids Res. 2009;38:D468-72.

https://doi.org/10.1093/nar/gkp1001

77. Benndorf D, Vogt C, Jehmlich N, Schmidt Y, Thomas H, Woffendin $\mathrm{G}$, et al. Improving protein extraction and separation methods for investigating the metaproteome of anaerobic benzene communities within sediments. Biodegradation. 2009;20(6):737-50. https://doi.org/10.1007/s10532-009-9261-3

78. Cardenas E, Tiedje JM. New tools for discovering and characterizing microbial diversity. Curr Opin Biotechnol. 2008; 19(6):544-9.

https://doi.org/10.1016/j.copbio.2008.10.010

79. Warnecke F, Hess M. A perspective: Metatranscriptomics as a tool for the discovery of novel biocatalysts. J Biotechnol. 2009;142(1):91-5. https://doi.org/10.1016/j.jbiotec.2009.03.022

80. Wilmes $P$, Andersson AF, Lefsrud MG, Wexler M, Shah M, Zhang $B$, et al. Community proteogenomics highlights microbial strain-variant protein expression within activated sludge performing enhanced biological phosphorus removal. ISME J. 2008;2:853-64.

https://doi.org/10.1038/ismej.2008.38
81. Wilmes $\mathrm{P}$, Wexler $\mathrm{M}$, Bond PL. Metaproteomics provides functional insight into activated sludge wastewater treatment. PLoS One. 2008;3(3):e1778.

https://doi.org/10.1371/journal.pone.0001778

82. Xing MN, Zhang $\mathrm{XZ}$, Huang $\mathrm{H}$. Application of metagenomic techniques in mining enzymes from microbial communities for biofuel synthesis. Biotechnol Adv. 2012;30(4):920-9. https://doi.org/10.1016/j.biotechadv.2012.01.021

83. Ferrer M, Martínez-Abarca F, Golyshin PN. Mining genomes and "metagenomes" for novel catalysts. Curr Opin Biotechnol. 2005;16(6):588-93.

https://doi.org/10.1016/j.copbio.2005.09.001

84. Kalyuzhnaya MG, Lapidus A, Ivanova N, Copeland AC, McHardy AC, Szeto E, et al. High-resolution metagenomics targets specific functional types in complex microbial communities. Nat Biotechnol. 2008;26(9):1029-34.

https://doi.org/10.1038/nbt.1488

85. Feist AM, Herrgård MJ, Thiele I, Reed JL, Palsson BØ. Reconstruction of biochemical networks in microorganisms. Nat Rev Microbiol. 2009;7(2):129-43.

https://doi.org/10.1038/nrmicro1949

86. Ward N. New directions and interactions in metagenomics research. FEMS Microbiol Ecol. 2006;55(3):331-8.

https://doi.org/10.1111/j.1574-6941.2005.00055.x

87. Courtois S, Cappellano CM, Ball M, Francou FX, Normand P, Helynck G, et al. Recombinant environmental libraries provide access to microbial diversity for drug discovery from natural products. Appl Environ Microbiol. 2003;69(1):49-55. https://doi.org/10.1128/AEM.69.1.49-55.2003

88. Aharoni A. Mining for new enzymes. Microb Biotechnol. 2009;2(2):128-9.

https://doi.org/10.1111/j.1751-7915.2009.00090_1.x

89. Westermeier $\mathrm{R}$, Marouga R. Protein detection methods in proteomics research. Biosci Rep. 2005;25(1-2):19-32.

https://doi.org/10.1007/s10540-005-2845-1

90. Gloux K, Leclerc M, Iliozer H, L'Haridon R, Manichanh C, Corthier $\mathrm{G}$, et al. Development of high-throughput phenotyping of metagenomic clones from the human gut microbiome for modulation of eukaryotic cell growth. Appl Environ Microbiol. 2007;73(11):3734-7.

https://doi.org/10.1128/AEM.02204-06

91. Suenaga $\mathrm{H}, \mathrm{Ohnuki}$, Miyazaki K. Functional screening of a metagenomic library for genes involved in microbial degradation of aromatic compounds. Environ Microbiol. 2007; 9(9):2289-97.

https://doi.org/10.1111/j.1462-2920.2007.01342.x

92. Uchiyama T, Miyazaki K. Functional metagenomics for enzyme discovery: Challenges to efficient screening. Curr Opin Biotechnol. 2009;20(6):616-22.

https://doi.org/10.1016/j.copbio.2009.09.010 
93. Vieites JM, Guazzaroni ME, Beloqui A, Golyshin PN, Ferrer M. Metagenomics approaches in systems microbiology. FEMS Microbiol Rev. 2009;33(1):236-55. https://doi.org/10.1111/j.1574-6976.2008.00152.x

94. Coyotzi S, Pratscher J, Murrell JC, Neufeld JD. Targeted metagenomics of active microbial populations with stable-isotope probing. Curr Opin Biotechnol. 2016;41:1-8. https://doi.org/10.1016/j.copbio.2016.02.017

95. Brady AL, Sharp CE, Grasby SE, Dunfield PF. Anaerobic carboxydotrophic bacteria in geothermal springs identified using stable isotope probing. Front Microbiol. 2015;6:897. https://doi.org/10.3389/fmicb.2015.00897

96. Behrens GA, Hummel A, Padhi SK, Schätzle S, Bornscheuer UT. Discovery and protein engineering of biocatalysts for organic synthesis. Adv Synth Catal. 2011;353(13):2191-215. https://doi.org/10.1002/adsc.201100446

97. Sturmberger L, Wallace PW, Glieder A, Birner-Gruenberger R. Synergism of proteomics and mRNA sequencing for enzyme discovery. J Biotechnol. 2016;235:132-8. https://doi.org/10.1016/j.jbiotec.2015.12.015

98. Su C, Gong JS, Zhang RX, Tao LY, Dou WF, Zhang DD, et al. A novel alkaline surfactant-stable keratinase with superior feather-degrading potential based on library screening strategy. Int J Biol Macromol. 2017;95:404-11. https://doi.org/10.1016/j.ijbiomac.2016.11.045

99. Abdullah N, Sulaiman F. The oil palm wastes in Malaysia. In: Matovic MD, editor. Biomass now - Sustainable growth and use. London, UK: IntechOpen Limited; 2013. https://doi.org/10.5772/55302

100. Wang JJ, Rojanatavorn K, Shih JCH. Increased production of Bacillus keratinase by chromosomal integration of multiple copies of the kerA gene. Biotechnol Bioeng. 2004; 87(4):459-64.

https://doi.org/10.1002/bit.20145

101. Kothari D, Rani A, Goyal A. Keratinases: In: Pandey A, Negi $\mathrm{S}$, Soccol CR, editors. Current developments in biotechnology and bioengineering. Oxford, UK: Elsevier BV; 2017. pp. 447-71.

102. Yang Z, Zhang Z. Engineering strategies for enhanced production of protein and bio-products in Pichia pastoris: A review. Biotechnol Adv. 2018;36(1):182-95. https://doi.org/10.1016/j.biotechadv.2017.11.002

103. Fang Z, Zhang J, Du G, Chen J. Rational protein engineering approaches to further improve the keratinolytic activity and thermostability of engineered keratinase KerSMD. Biochem Eng J. 2017;127:147-53. https://doi.org/10.1016/j.bej.2017.08.010

104. Liu B, Zhang J, Fang Z, Gu L, Liao X, Du G, Chen J. Enhanced thermostability of keratinase by computational design and empirical mutation. J Ind Microbiol Biotechnol. 2013;40(7):697-704.

https://doi.org/10.1007/s10295-013-1268-4
105. Estell DA, Graycar TP, Wells JA. Engineering an enzyme by site-directed mutagenesis to be resistant to chemical oxidation. J Biol Chem. 1985;260(11):6518-21.

106. Uria AR, Fawzya YN, Chasanah E. Novel molecular methods for discovery and engineering of biocatalysts from uncultured marine microorganisms. J Coast Dev. 2005;8(2):4974.

107. Wahler D, Reymond JL. Novel methods for biocatalyst screening. Curr Opin Chem Biol. 2001;5(2):152-8. https://doi.org/10.1016/S1367-5931(00)00184-8

108. Zhang H, Fang J, Deng Y, Zhao Y. Optimized production of Serratia marcescens B742 mutants for preparing chitin from shrimp shells powders. Int J Biol Macromol. 2014; 69:319-28.

https://doi.org/10.1016/j.ijbiomac.2014.05.058

109. Cai C, Lou B, Zheng X. Keratinase production and keratin degradation by a mutant strain of Bacillus subtilis. J Zhejiang Univ Sci B. 2008;9(1):60-7. https://doi.org/10.1631/jzus.B061620

110. Zaraî Jaouadi N, Rekik H, Ben Elhoul M, Zohra Rahem F, Hila CG, Ben Aicha HS, et al. A novel keratinase from Bacillus tequilensis strain Q7 with promising potential for the leather bating process. Int J Biol Macromol. 2015;79:952-64. https://doi.org/10.1016/j.ijbiomac.2015.05.038

111. Zeng YH, Shen FT, Tan CC, Huang CC, Young CC. The flexibility of UV-inducible mutation in Deinococcus ficus as evidenced by the existence of the imuB-dnaE2 gene cassette and generation of superior feather degrading bacteria. Microbiol Res. 2011;167(1):40-7. https://doi.org/10.1016/j.micres.2011.02.008

112. Schlabach MR, Hu JK, Li M, Elledge SJ. Synthetic design of strong promoters. Proc Natl Acad Sci. 2010;107(6):2538-43. https://doi.org/10.1073/pnas.0914803107

113. Wang JJ, Swaisgood HE, Shih JCH. Bioimmobilization of keratinase using Bacillus subtilis and Escherichia coli systems. Biotechnol Bioeng. 2003;81(4):421-9. https://doi.org/10.1002/bit.10485

114. Johannes TW, Zhao H. Directed evolution of enzymes and biosynthetic pathways. Curr Opin Microbiol. 2006;9(3): 261-7. https://doi.org/10.1016/j.mib.2006.03.003

115. Arnold FH. Combinatorial and computational challenges for biocatalyst design. Nature. 2001;409:253-7. https://doi.org/10.1038/35051731

116. Xiao H, Bao Z, Zhao H. High throughput screening and selection methods for directed enzyme evolution. Ind Eng Chem Res. 2015;54(16):4011-20. https://doi.org/10.1021/ie503060a

117. Wahler D, Reymond JL. High-throughput screening for biocatalysts. Curr Opin Biotechnol. 2001;12(6):535-44. https://doi.org/10.1016/S0958-1669(01)00260-9 
118. Sumantha A, Larroche C, Pandey A. Microbiology and industrial biotechnology of food-grade proteases: A perspective. Food Technol Biotechnol. 2006;44:211-20.

119. Bálint B, Bagi Z, Tóth A, Rákhely G, Perei K, Kovács KL. Utilization of keratin-containing biowaste to produce biohydrogen. Appl Microbiol Biotechnol. 2005;69(4):404-10. https://doi.org/10.1007/s00253-005-1993-3

120. Paul T, Jana A, Mandal AK, Mandal A, Das Mohpatra PK, Mondal KC. Bacterial keratinolytic protease, imminent starter for NextGen leather and detergent industries. Sustain Chem Pharm. 2016;3:8-22.

http://doi.org/10.1016/j.scp.2016.01.001

121. Kandasamy S, Duraisamy S, Chinnappan S, Balakrishnan $S$, Thangasamy S, Muthusamy G, et al. Molecular modeling and docking of protease from Bacillus sp. for the keratin degradation. Biocatal Agric Biotechnol. 2018;13:95-104. http://doi.org/10.1016/j.bcab.2017.11.016

122. Jaouadi B, Ellouz-Chaabouni S, Ali MB, Messaoud EB, Naili B, Dhouib A, Bejar S. Excellent laundry detergent compatibility and high dehairing ability of the Bacillus pumilus CBS alkaline proteinase (SAPB). Biotechnol Bioprocess Eng. 2009;14(4):503-12.

https://doi.org/10.1007/s12257-008-0244-8

123. Rajkumar R, Jayappriyan KR, Rengasamy R. Purification and characterization of a protease produced by Bacillus megaterium RRM2: Application in detergent and dehairing industries. J Basic Microbiol. 2011;51:614-24.

https://doi.org/10.1002/jobm.201000517

124. Sivasubramanian S, Murali Manohar B, Rajaram A, Puvanakrishnan R. Ecofriendly lime and sulfide free enzymatic dehairing of skins and hides using a bacterial alkaline protease. Chemosphere. 2008;70(6):1015-24. https://doi.org/10.1016/j.chemosphere.2007.09.036

125. Sivasubramanian S, Murali Manohar B, Puvanakrishnan R. Mechanism of enzymatic dehairing of skins using a bacterial alkaline protease. Chemosphere. 2008;70(6):1025-34. https://doi.org/10.1016/j.chemosphere.2007.07.084

126. Sundararajan S, Kannan CN, Chittibabu S. Alkaline protease from Bacillus cereus VITSN04: potential application as a dehairing agent. J Biosci Bioeng. 2011;111(2):128-33. https://doi.org/10.1016/j.jbiosc.2010.09.009

127. Chaturvedi V, Bhange K, Bhatt R, Verma P. Production of keratinases using chicken feathers as a substrate by a novel multifunctional strain of Pseudomonas stutzeri and its dehairing application. Biocatal Agric Biotechnol. 2014; 3(2):167-74.

https://doi.org/10.1016/j.bcab.2013.08.005

128. Bouacem K, Bouanane-Darenfed A, Zaraî Jaouadi N, Joseph $M$, Hacene $H$, Ollivier B, et al. Novel serine keratinase from Caldicoprobacter algeriensis exhibiting outstanding hide dehairing abilities. Int J Biol Macromol. 2016;86:321-8. https://doi.org/10.1016/j.ijbiomac.2016.01.074
129. Zhang RX, Gong JS, Zhang DD, Su C, Hou YS, Li H, et al. A metallo-keratinase from a newly isolated Acinetobacter sp. R-1 with low collagenase activity and its biotechnological application potential in leather industry. Bioprocess Biosyst Eng. 2016;39(1):193-204.

https://doi.org/10.1007/s00449-015-1503-7

130. PaulT, Das A, Mandal A, Jana A, Maity C, Adak A, et al. Effective dehairing properties of keratinase from Paenibacillus woosongensis TKB2 obtained under solid state fermentation. Waste Biomass Valor. 2014;5:97-107.

https://doi.org/10.1007/s12649-013-9217-z

131. George N, Sondhi S, Soni SK, Gupta N. Lime and sulphide-free dehairing of animal skin using collagenase-free alkaline protease from Vibrio metschnikovii NG155. Indian J Microbiol. 2014;54(2):139-42.

https://doi.org/10.1007/s12088-013-0434-8

132. Dayanandan A, Kanagaraj J, Sounderraj L, Govindaraju R, Suseela Rajkumar G. Application of an alkaline protease in leather processing: an ecofriendly approach. J Clean Prod. 2003;11(5):533-6. https://doi.org/10.1016/S0959-6526(02)00056-2

133. Ismail AMS, Housseiny MM, Abo-Almagd HI, El-Sayed NH, Habib M. Novel keratinase from Trichoderma harzianum $\mathrm{MH}-20$ exhibiting remarkable 24 dehairing capabilities. Int Biodeterior Biodegrad. 2012;70:14-19.

https://doi.org/10.1016/jibiod.2011.10.013

134. Zhang RX, Gong JS, Su C, Zhang DD, Tian H, Dou WF, et al. Biochemical characterization of a novel surfactant-stable serine keratinase with no collagenase activity from Brevibacillus parabrevis CGMCC 10798. Int J Biol Macromol. 2016;93(Pt. A):843-51. https://doi.org/10.1016/j.jjbiomac.2016.09.063

135. Dettmer A, Cavalli É, Ayub MAZ, Gutterres M. Optimization of the unhairing leather processing with enzymes and the evaluation of inter-fibrillary proteins removal: An environment-friendly alternative. Bioprocess Biosyst Eng. 2012;35(8):1317-24. https://doi.org/10.1007/s00449-012-0719-z

136. Koehn H, Clerens S, Deb-Choudhury S, Morton JD, Dyer JM, Plowman JE. The proteome of the wool cuticle. J Proteome Res. 2010;9(6):2920-8. https://doi.org/10.1021/pr901106m

137. Gupta R, Rajput R, Sharma R, Gupta N. Biotechnological applications and prospective market of microbial keratinases. Appl Microbiol Biotechnol. 2013;97(23):9931-40. https://doi.org/10.1007/s00253-013-5292-0

138. Shen J, Rushforth M, Cavaco-Paulo A, Guebitz G, Lenting $\mathrm{H}$. Development and industrialisation of enzymatic shrink-resist process based on modified proteases for wool machine washability. Enzyme Microb Technol. 2007; 40(7):1656-61.

https://doi.org/10.1016/j.enzmictec.2006.07.034 
139. Tsiroulnikov K, Rezai H, Bonch-Osmolovskaya E, Nedkov P, Gousterova A, Cueff V, et al. Hydrolysis of the amyloid prion protein and nonpathogenic meat and bone meal by anaerobic thermophilic prokaryotes and Streptomyces subspecies. J Agric Food Chem. 2004;52(20):6353-60. https://doi.org/10.1021/jf0493324

140. Friedrich J, Gradišar H, Vrecl M, Pogačnik A. In vitro degradation of porcine skin epidermis by a fungal keratinase of Doratomyces microsporus. Enzyme Microb Technol. 2005; 36(4):455-60.

https://doi.org/10.1016/j.enzmictec.2004.09.015

141. Gradišar H, Friedrich J, Križaj I, Jerala R. Similarities and specificities of fungal keratinolytic proteases: Comparison of keratinases of Paecilomyces marquandii and Doratomyces microsporus to some known proteases. Appl Environ Microbiol. 2005;71(7):3420-6.

https://doi.org/10.1128/AEM.71.7.3420-3426.2005

142. Kumar TP, Raju PN. Transungual drug delivery: A promising route to treat nail disorders. Int J Pharma Res Rev. 2013;2(4):22-33.

143. Mohorčič M, Torkar A, Friedrich J, Kristl J, Murdan S. An investigation into keratinolytic enzymes to enhance ungual drug delivery. Int J Pharm. 2007;332(1-2):196-201.

https://doi.org/10.1016/j.ijpharm.2006.09.042

144. Rajendra VB, Baro A, Kumari A, Dhamecha DL, Lahoti SR, Shelke SD. Transungual drug delivery: An overview. J Appl Pharm Sci. 2012;2(1):203-9.

145. Korniłłowicz-Kowalska T, Bohacz J. Biodegradation of keratin waste: Theory and practical aspects. Waste Manag. 2011;31(8):1689-701.

https://doi.org/10.1016/j.wasman.2011.03.024

146. Łaba W, Kopeć W, Chorazyk D, Kancelista A, Piegza M, Malik K. Biodegradation of pretreated pig bristles by Bacillus cereus B5esz. Int Biodeterior Biodegrad. 2015;100:116-23. https://doi.org/10.1016/j.ibiod.2015.02.024

147. Haddar A, Sellami-Kamoun A, Fakhfakh-Zouari N, Hmidet $\mathrm{N}$, Nasri M. Characterization of detergent stable and feather degrading serine proteases from Bacillus mojavensis A21. Biochem Eng J. 2010;51(1-2):53-63.

https://doi.org/10.1016/j.bej.2010.05.002

148. Li Q, Gao KQ, Meng Q, Clarke JA, Shawkey MD, D’Alba L, et al. Reconstruction of Microraptor and the evolution of iridescent plumage. Science. 2012;335(6073):1215-9. https://doi.org/10.1126/science.1213780

149. Gousterova A, Braikova D, Goshev I, Christov P, Tishinov K, Vasileva-Tonkova $\mathrm{E}$, et al. Degradation of keratin and collagen containing wastes by newly isolated thermoactinomycetes or by alkaline hydrolysis. Lett Appl Microbiol. 2005;40(5):335-40.

https://doi.org/10.1111/j.1472-765X.2005.01692.x
150. Love DC, Halden RU, Davis MF, Nachman KE. Feather meal: A previously unrecognized route for reentry into the food supply of multiple pharmaceuticals and personal care products (PPCPs). Environ Sci Technol. 2012;46(7):3795802.

https://doi.org/10.1021/es203970e

151. Xia Y, Massé DI, McAllister TA, Beaulieu C, Ungerfeld E. Anaerobic digestion of chicken feather with swine manure or slaughterhouse sludge for biogas production. Waste Manag. 2012;32(3):404-9.

https://doi.org/10.1016/j.wasman.2011.10.024

152. Salminen EA, Rintala JA. Semi-continuous anaerobic digestion of solid poultry slaughterhouse waste: Effect of hydraulic retention time and loading. Water Res. 2002;36 (13):3175-82.

https://doi.org/10.1016/S0043-1354(02)00010-6

153. Angelidaki I, Sanders W. Assessment of the anaerobic biodegradability of macropollutants. Rev Environ Sci Biotechnol. 2004;3(2):117-29.

https://doi.org/10.1007/s11157-004-2502-3

154. Davidsson Å. Increase of biogas production at wastewater treatment plants: Addition of urban organic waste and pre-treatment of sludge [PhDThesis]. Lund, Sweden: Lund University; 2007.

155. Forgács G, Lundin M, Taherzadeh MJ, Sárvári Horváth I. Pretreatment of chicken feather waste for improved biogas production. Appl Biochem Biotechnol. 2011;169(7):2016-28. https://doi.org/10.1007/s12010-013-0116-3

156. Patinvoh RJ, Osadolor OA, Chandolias K, Sárvári Horváth I, Taherzadeh MJ. Innovative pretreatment strategies for biogas production. Bioresour Technol. 2017;224:13-24. https://doi.org/10.1016/j.biortech.2016.11.083

157. Coward-Kelly G, Chang VS, Agbogbo FK, Holtzapple MT. Lime treatment of keratinous materials for the generation of highly digestible animal feed: 1 . Chicken feathers. Bioresour Technol. 2006;97(11):1337-43. https://doi.org/10.1016/j.biortech.2005.05.021

158. Salminen E, Einola J, Rintala J. The methane production of poultry slaughtering residues and effects of pre-treatments on the methane production of poultry feather. Environ Technol. 2003;24(9):1079-86. https://doi.org/10.1080/09593330309385648

159. Gegeckas A, Gudiukaite R, Debski J, Citavicius D. Keratinous waste decomposition and peptide production by keratinase from Geobacillus stearothermophilus AD-11. Int J Biol Macromol. 2015;75:158-65. https://doi.org/10.1016/j.ijbiomac.2015.01.031

160. Zhang S, Long L, Yin H, Xiao Z, Li Q, Zhang S, et al. Pearl albefaction method mediated by keratinase and combined with redox. CN grant CN100579412C. 2010. 